hibitor and Fast Red TR salt solution in $3 \%$ aqueous dupanol as colour index. The results are summarized in the Table.

\begin{tabular}{|c|c|c|c|}
\hline Genetic Disorder & $\mid \begin{array}{c}\text { Number } \\
\text { inam- } \\
\text { ined }\end{array}$ & $\mid \begin{array}{c}\text { |Abnor- } \\
\text { mal } \\
\text { Cases }\end{array}$ & $\%$ \\
\hline $\begin{array}{l}\text { 6-thalassaemia trait } \\
\text { Hb A2 increased }(>3.5 \%) \\
\text { S thal. (Hb F > } 5 \% \text { ) } \\
\text { G-6-PD deficiency } \\
\text { Atypical ACAH .. }\end{array}$ & $\begin{array}{l}156 \\
156 \\
156 \\
155 \\
187^{*}\end{array}$ & $\begin{array}{r}27 \\
25 \\
2 \\
8 \\
13\end{array}$ & $\begin{array}{r}17 \cdot 3 \\
16 \cdot 0 \\
1 \cdot 3 \\
5 \cdot 2 \\
6 \cdot 9\end{array}$ \\
\hline
\end{tabular}

- Including 32 Cypriot students of Athen's University.

The prevalence of the $\beta$-thalassaemia trait was high in the sample examined. With a prevalence of $17.3 \%$ the birth rate of homozygous $\beta$-thalassaemia can be estimated to be $0.8 \%$. A relative birth rate of $0.6 \%$ was also found among Cypriots in London. ${ }^{5}$

Considering the severity of thalassaemia major these figures demonstrate its seriousness as a public health problem in Cyprus. Since at present there is no other way of reducing the birth rate of patients with thalassaemia major except by genetic counselling, it is suggested that the whole population at risk should be screened for the thalassaemia trait and careful genetic counselling provided to all prospective couples whenever both the prospective father and mother are heterozygous.

On the other hand, the prevalance of clinical manifestations associated with G-6PD deficiency, namely, favism and severe neonatal jaundice, seems to be higher than that expected on the basis of the rather low prevalence of G-6-PD deficiency (5.2\%). ${ }^{6}$ It should be noted in this respect that in addition to G-6-PD deficiency other unknown factors, probably genetic, may be responsible for precipitating clinical manifestations in sensitive individuals.

Interestingly we found a relatively high prevalence of atypical ACAH; this is generally believed to be geographically distributed rather homogeneously with a prevalence of about $4 \%{ }^{7}$ The higher prevalence observed in this study (6.9\%) may partly explain why a number of the first cases of suxamethonium apnoeas and some of the rare abnormal ACAH genotypes were described in Cypriots residing in England. We are, etc.,

Christos Kattamis StaVRos HaIdas AnNa Metaxotou-MaVRomat Nicolas Matsaniotis

Department of Paediatrics,

"Athens University Soph" ‘" Children's Hospital,

Athens 608, Greece

1 World Health Organization. Haemoglobinopathies and Allied Disorders, Tech. Rep. Ser., No. 338 , Geneva, 1966

Banton, A. H.: American fournal of Human

Genetics, $1951,3.47$.

H., C. C., Rucknagel, D. L., and Gerchow:t 16. 267.

- Kattamis. C., Lagos, P. Metaxotou, A.,

Matsaniotis, N., fournal of Medical Genetics,

1972, 9, 154. Benson, A., and Payling-Wright, Modell, C. B., Benson,

7 Kattamis, C., et al., Nature, 1962, 196, 599.

\section{Herpes Simplex and Temporal Lobe} Epilepsy

SIR,-We were interested in Dr. Constance A. C. Ross's letter (8 July, p. 112) concerning herpes simplex virus and temporal lobe epilepsy. Following a report ${ }^{1}$ that patients with an aggressive psychosis had a very high titre of antibody to herpes simplex virus compared with controls we conducted a small survey of sera from nine cases of temporal lobe epilepsy, 14 cases of idiopathic epilepsy, and 23 normal controls, matched for age and sex. When we used the fluorescent antibody method to detect herpes virus-specific IgM and to measure the titre of IgG against herpes simplex virus there was no significant difference in antibody titre between the three groups, and herpes virusspecific IgM was not found in any serum.

The results do not exclude past damage by herpes simplex virus but make continuous active infection unlikely. We agree with Dr. Ross that antibody titres should be checked on paired sera.-We are, etc.,

Royal Victoria Hospital

J. H. D. MILLAR

MARgARET HAIRE

K. B. FrASER

Department of Microbiology,

Queen's

1 Cleobury, J. F., Skinner, G. R. B., Thouless, M. E., and Wildy, P., British Medical fournal,
$1971,1,438$.

\section{Virus-specific Antibodies in Multiple Sclerosis}

SIR,-Some patients with multiple sclerosis were found by the fluorescent antibody method to possess measles virus-specific immunoglobulin $\mathrm{M}$ (IgM). ${ }^{1}$ A second survey made on 57 sera from multiple sclerosis and 57 from individuals in normal health matched for age and sex, has confirmed these findings and has added some information on virus-specific immunoglobulin G (IgG), detected by the same method.

IgM specific for measles virus-infected cells.-The incidence of IgM staining by sera from multiple sclerosis on measles virusinfected cells appears in Table 1 . The staining is weak and the pattern diffuse, slightly brighter at the cell margin, and leaves unstained known intracellular aggregates of virus antigen. It was not seen in cells infected with the viruses of mumps, herpes simplex, varicella, vaccinia, or rubella. It is not removed from serum by normal brain tissue. It is removed by absorption with crudely pelleted measles virus and from about half the sera by absorption with aggregated human gamma globulin. This may indicate secondary staining by rheumatoid factor, but nevertheless is immunological. ${ }^{2}$

Table 1-Number of Sera Showing IgM Staining of Measles Virus-infected $\mathrm{HEP}_{2}$ cells

\begin{tabular}{|c|c|c|c|}
\hline \multicolumn{2}{|c|}{$\begin{array}{l}\text { Multiple Sclerosis } \\
\text { (56 sera) } \\
\text { Absorption with } \\
\text { aggregated gamma } \\
\text { globulin }\end{array}$} & \multicolumn{2}{|c|}{$\begin{array}{c}\text { Controls } \\
\text { (56 sera) } \\
\text { Absorption with } \\
\text { aggregated gamma } \\
\text { globulin }\end{array}$} \\
\hline Before & After & Before & After \\
\hline 22 & 9 & 1 & 0 \\
\hline
\end{tabular}

Titres of virus-specific IgG.-As may be expected, ${ }^{3}$ we found a significant increase of measles virus-specific IgG in multiple sclerosis patients as compared with control subjects (Table 2). We were surprised to find an equally clear increase of herpes simplex virus-specific $\operatorname{IgG}$, but none against rubella virus. Titres against mumps or herpes zoster viruses were low and not different in the two groups.

Table 2-Geometric Mean Titres (reciprocal) of Virus-specific IgG in 57 Pairs of Sera

\begin{tabular}{|c|c|c|c|}
\hline & $\begin{array}{l}\text { Multiple } \\
\text { sclerosis }\end{array}$ & $\begin{array}{l}\text { Normal } \\
\text { controls }\end{array}$ & $\begin{array}{c}\text { Significance } \\
\boldsymbol{x}^{2}(\mathrm{df}=1)\end{array}$ \\
\hline Measles virus & 31.4 & 18.3 & $9.03: P<0.01$ \\
\hline $\begin{array}{l}\text { Herpes-simplex } \\
\text { virus } \\
\text { Rubella virus }\end{array}$ & $\begin{array}{l}40 \cdot 8 \\
25 \cdot 9\end{array}$ & $\begin{array}{l}17 \cdot 5 \\
25 \cdot 7\end{array}$ & $\begin{array}{l}7.19: P<<0.01 \\
0.55: P>0.40\end{array}$ \\
\hline
\end{tabular}

Virus-specific IgG in cerebrospinal fluid. -Serum and cerebrospinal fluid taken together from 25 patients and 17 normal subjects of about the same age as the patients, were tested for the presence of antibody to the viruses of measles, mumps, and herpes simplex and some, 16 multiple sclerosis and 11 control, for IgG to rubella virus. Sixteen of 25 patients had measles virus-specific IgG in cerebrospinal fluid and 8 of these 16 also had IgG specific for herpes simplex virus. No rubella IgG was found in the C.S.F. No virus-specific IgM was detected in any C.S.F. and no virus-specific IgG in controls.

The presence in serum of IgM specific for a minor component only of measlesinfected cells may be related to a report (personal communication, Dr. E. Norrby) that some multiple sclerosis sera have more antibody against measles virus haemolysin than against virus haemagglutinin. It could also represent a cross-reaction with some other infectious agent or tissue or haemolysin.

Similar examination of cerebrospinal fluids from other chronic or subacute diseases of the central nervous system will show whether the particular IgM reacting with measles virus is characteristic of multiple sclerosis and also how often such fluids contain immunoglobulins specific for more than one virus.-We are, etc.,

K. B. Fraser MARGARET HAIRE

Department of Microbiology,

J. H. D. MILlaR

Royal Victoria Hospital,

1 Millar, J. H. D., et al., British Medical fournal, 1971, 2, 378. K. B., Annals of the Rheumatic Diseases, (in

3 Adams, J. M., Brooks, M. B. Fisher, E. D., and Tyler, C.' S., Neurology, 1970, 20, 1039.
and

\section{E.N.T. Advances}

SIR,-In a review (22 July, p. 243) Mr. John Ballantyne raised the question whether there was a place for books which discuss trends of modern development in a specialty. I do not intend to dispute whether this is so or not, but I would like to take issue with the examples given in favour of his argument. He pointed out that omissions of most recent advances are inevitable in book; of this type and gives as an example the lark of reference to electrocochleography, which in his opinion is "almost certainly destined to become the best objective test of cochlear function for many years to come."

Electrocochleooraphy was in a very experimental stage when I wrote the chapter on the deaf child in this book, but were I to write it tolay I still might have omitted cochleography. Many "objective" tests have 
been received with great enthusiasm as the solution to difficulties encountered in testing the hearing of uncooperative subjects. The psychogalvanic skin resistance test, for example, was a few years ago hailed as the final answer. In many centres expensive equipment was installed only to find later that the results were unreliable. More recently E.E.G. audiometry has been also received with equally great enthusiasm. In some E.N.T. departments thousands of pounds have been invested to purchase the apparatus in the belief that there was no need for other facilities for child audiology. There is no conclusive evidence that this method provides the answers in children who are extremely difficult, have additional brain damage, cerebral palsied, etc. These are precisely the children for whom we want a truly reliable objective test.

There is still serious doubt whether electrocochleography provides answers which could not be obtained by the simpler methods, which are also more informative about many other aspects of the child's function. Cochleography can record only the potentials resulting from the stimulation of the peripheral receptor. Various types of hearing loss in children-especially high frequency losses-are caused not by damage in the cochlea but in the cochlear nuclei in the auditory pathway. It is possible to combine cochleography and evoked response audiometry to cover the whole auditory system, but in view of the inadequacy of the evoked-response technique in many children this procedure would be in question in any case. Cochleography in children is possible only under general anaesthesia and the procedure is laborious and time consuming. It cannot be used as a routine clinical procedure at present. This would not matter if truly it gave results unobtainable otherwise, but there is still serious doubt about that.

The enthusiasm for new "objective" tests is always greatest when no proper facilities for child audiology exist, in the hope that a technical procedure will take the place of proper provision for clinical audiology. One of the main reasons for the failure of socalled objective tests is that certain physiological principles concerning the responses of children to sensory stimulation are disregarded-for example, the law of initial values, problems of habituation, of inhibition, etc. In my chapter I did discuss the problems of objective hearing tests and indicated clearly what should be a favourable development. Electrocochleography is still a highly experimental procedure, and I have serious doubts whether, as Ballantyne puts it, it is "destined to become the best objective test of cochlear function."-I am, etc.,

L. FIscH

Institute of Laryngology and Otology,

Pancreatin as Source of Salmonella

SIR,-Dr. E. J. G. Glencross's report (13 May, p. 376) prompts us to report the following cases.

In December 1968 a baby aged 2 months was admitted to the Royal Albert Edward Infirmary, Wigan, with cystic fibrosis. The diagnosis had been established three weeks earlier and treatment with pancreatin started. She had an acute illness with diarrhoea and vomiting, and this proved to be associated with a growth of Salmonella bovis morbificans. Three other children on the ward contracted the same infection and one of them (who also suffered from multiple congenital abnormality) died. One of the nursing staff also became infected.

In September 1969 the same organism was isolated from a 7-month-old child in Booth Hall Hospital, Manchester. He also was receiving pancreatin for cystic fibrosis. He had an acute diarrhoeal episode when the organism was first isolated. This lasted only 48 hours, though he continued to carry the salmonella for six weeks. He had had no known contact with the other cases. One other child in Booth Hall Hospital became infected. He suffered from epidermolysis bullosa, from which he died at the age of 9 months. Salmonella was cultured from his stools for only three weeks.

Powder, granules, and capsules from two batches of the pancreatin used in both hospitals were cultured in Selenite broth and subcultured after 18 hours into desoxycholate citrate agar. No salmonellae were grown.

This particular salmonella is extremely rare in human infections, but well known in pigs and cattle. Because we were unable to prove the sources of the infection we felt unable to publish these cases at the time, but in the light of this new evidence we feel that it is useful to do so.-We are, etc.,

\section{R. M. FORRESTER}

Royal Albert Edward Infirmary Wigan, Lancs

Booth Hall Children's Hospital,

J. H. KEEN Blackley, Manchester

\section{Anaesthesia by Acupuncture}

SIR,-It is, of course, essential that anaesthesia by acupuncture be investigated thoroughly and without prejudice, but this is by no means the first example of major surgery being performed painlessly without general anaesthesia.

In the 1840s Surgeon James Esdaile, of the Indian Medical Service, performed hundreds of major operations in Bengal under hypnotic suggestion; his success was acclaimed all over the world. After investigation by a committee presided over by the Inspector-General of Civil Hospitals, Bengal, a Mesmer hospital was started in Calcutta. Large tumours were removed without pain in a high proportion of cases. Seven out of 10 patients in one series were successfully mesmerized before operation. The advent of chloroform anaesthesia with $100 \%$ success put an end to Esdaile's work, details of which may be found in Crawford's History of the Indian Medical Service. ${ }^{1}-\mathrm{I}$ am, etc.,

Ewell, Surrey

GEORGe R. MCROBERT

1 Crawford, D. G., History of the Indian Medical Service. Vol. 2.' London, Thacker and Co., 1914

\section{Effects of Dietary Fibre}

SIR,-The notion that a rapid and serious fall in consumption of dietary fibre by the British population followed the introduction of roller milling in about 1880 , and has thus been the cause of various diseases of civilization, ${ }^{1}$ is mistaken. There is evidence that even in the late 1840 's, and probably for several years before, the "crude fibre" of the usual bread flour did not exceed $0.5 \%$ at the very most. ${ }^{2}$ Over the next 50 years its fibre content was gradually reduced by various milling developments and by the use of new wheats of better milling quality to current levels $(0 \cdot 1-0 \cdot 15 \%)$. Moreover, ${ }^{3}$ there has been no fall in the fibre content of the British diet over the past 100 years, though the relative contributions of its sources have changed appreciably.

The clinical basis for the "low-residue" theory of the cause of diverticular and other serious diseases of the colon rests on reported differences in faecal bulk and consistency, as a result of high- or low-residue diets, causing large differences in intestinal transit time of faeces. ${ }^{14}$ Though low-residue diets produce low-bulk stools, the clinical significance of any difference in transit times resulting from diets differing only in the fibre contributed by the flour component requires further study under British conditions. Comparisons of inhabitants of the U.K. with African communities of much lower life expectation, or of the latter communities with Negro populations elsewhere, inextricably intermix major differencesgenetic, medical, ${ }^{5}$ environmental (for example, bowel infections and infestation), as well as dietary changes such as the much higher fat and sugar content of "Western" diets. It could be alleged that the lower expectation of life in African communities may be partly due to excessive consumption of vegetable roughage. ${ }^{7}$ Crawford and coworkers draw attention to Burkitt's own work on the association of certain high bulk diets with adult intussusception, volvulus, and double volvulus. The excessive use of bulking agents (including wheat bran) may itself be hazardous. ${ }^{8}$ Some individuals cannot tolerate high residue diets.

In correspondence in this journal the rarity of certain diseases in developing countries has been questioned by Osuntokun.9 Goulston ${ }^{10}$ has disagreed with the statements of Cleave and Campbell11 on the incidence of diverticular disease in Ethiopia, while Dr. A. O. H. Tellegen (20 May, p. 467) has contradicted Captain T. L. Cleave's statement (4 March, p. 629) on the rari y of venous disorders in Africa.

The study of diverticulosis in rats cited by Painter and Burkitt ${ }^{1}$ involved numerous groups of animals in an experiment which does not permit the logical separation of the effects of high dietary fibre from other major factors. Indeed, a major weakness of the evidence presented for the prophylactic, or therapeutic, action of bran is the lack of direct intercomparisons of the effects on health or life expectation of its presence in, or absence from, otherwise identical diets. Consideration of the references ${ }^{19-11}$ relative to high pressures in the colon show that these pressures could not be demonstrated under basal conditions, and only developed under the influence of prostigmine. Under these conditions their relevance to the development of the disease seems uncertain.

Some of the other evidence for the CleavePainter-Burkitt hypothesis 14 appears to be statistically unsound. For example, the difference in incidence of diverticular disease in two locations, stated ${ }^{4}$ to be significant at the $5 \%$ level, is not significant even at the $30 \%$ level. Painter and Burkitt's graph of the mortality data for diverticular disease shows no sex differentiation from 1923-52, and then a rapid rise in female mortality 